Article

\title{
Impact of Nitrate and Ammonium Ratios on Flowering and Asexual Reproduction in the Everbearing Strawberry Cultivar Fragaria $\times$ ananassa Albion
}

\author{
Xiaonan Shi, Ricardo Hernández and Mark Hoffmann * \\ Department of Horticultural Science, North Carolina State University, Raleigh, NC 27695, USA; \\ xshi8@ncsu.edu (X.S.); ricardo_hernandez@ncsu.edu (R.H.) \\ * Correspondence: mark.hoffmann@ncsu.edu
}

Citation: Shi, X.; Hernández, R.; Hoffmann, M. Impact of Nitrate and Ammonium Ratios on Flowering and Asexual Reproduction in the Everbearing Strawberry Cultivar Fragaria $\times$ ananassa Albion Horticulturae 2021, 7, 571. https:/ / doi.org/10.3390/horticulturae7120571

Academic Editor: Esmaeil Fallahi

Received: 18 October 2021

Accepted: 10 December 2021

Published: 12 December 2021

Publisher's Note: MDPI stays neutral with regard to jurisdictional claims in published maps and institutional affiliations.

Copyright: (c) 2021 by the authors. Licensee MDPI, Basel, Switzerland. This article is an open access article distributed under the terms and conditions of the Creative Commons Attribution (CC BY) license (https:/ / creativecommons.org/licenses/by/ $4.0 /)$.
Abstract: Ever-bearing (EB) strawberries are long-day cultivars that show perpetual flowering behavior. Compared to June-bearing short-day cultivars, EB cultivars can initiate flowers with less dependency on light and temperature levels. This leads to a more consistent flowering and fruiting pattern, making EB cultivars favorable for areas with long growing seasons. However, this flowering pattern also brings significant challenges to open-field strawberry nurseries. Consistent flower development in EB cultivars frequently leads to increased labor cost for manual flower removal on nursery ground. The alteration of flowering behavior via fertilizer regimes could be a cost-effective tool for strawberry nurseries. However, while it is known that the source of nitrogen $(\mathrm{N})$ impacts strawberry flowering, its effect on strawberry propagation rates needs further investigation. The objective of this study was to investigate the impact of nitrate $\left(\mathrm{NO}_{3}{ }^{-}\right)$to ammonium $\left(\mathrm{NH}_{4}{ }^{+}\right)$ratio on flower and daughter plant production in the EB strawberry cultivar 'Albion' (Fragaria $\times$ ananassa c.v. 'Albion'). Strawberry plants were grown in a completely randomized design under greenhouse conditions $\left(26.6{ }^{\circ} \mathrm{C}, 16 \mathrm{~h}\right.$ photoperiod). Four treatments of $\mathrm{NO}_{3}{ }^{-}: \mathrm{NH}_{4}{ }^{+}$were implemented: (1) 100\%:0\%; (2) 80\%:20\%; (3) 60\%:40\%; (4) 50\%:50\%. Strawberry plants fertilized with a 60\%:40\% $\mathrm{NO}_{3}{ }^{-}: \mathrm{NH}_{4}{ }^{+}$ratio produced $17-31 \%$ fewer inflorescences than those fertilized with 100\%:0\% $(8.8 \pm 1.19)$ and $80 \%: 20 \%(10.3 \pm 1.85)$ ratios. The production of daughter plants remained similar in all four treatments. Our results show that increased ratios of ammonium in combination with decreased ratios of nitrate reduce flowering of EB strawberry cultivars, while propagation rates remain consistent. These results could potentially lead to the development of fertilizer regimes for strawberry nurseries to reduce flower production in EB cultivars.

Keywords: strawberry propagation; ever-bearing; fertilizer

\section{Introduction}

Strawberries (Fragaria spec.) are herbaceous perennials belonging to the family Rosaceae. The commercial strawberry plant (Fragaria $\times$ ananassa) is an octoploid hybrid and mostly grown in annual systems for fruit production. The total US production value of strawberries was approximately 2.5 billion USD in 2019 [1]. Strawberry nurseries created an additional value of approximately 166 million USD [2]. While strawberry production systems are annualized, open-field strawberry nurseries are multiyear and multilocation operations in which plants are reproduced asexually. This reproduction process is called 'runnering', referring to the development of aerial stolons with a sympodial unit that is composed of two internodes and a daughter plant. Daughter plants are new leaf rosettes, genetically identical to the mother plant and with the ability to develop into a complete strawberry plant [3].

Strawberry cultivars are often classified on the basis of their flowering behavior: seasonal flowering, also referred to as short-day (SD) or June-bearing cultivars, and perpetual flowering, often referred to as ever-bearing (EB) or long-day cultivars. SD strawberry 
cultivars have the feature of one flush of flowering and fruiting in spring and early summer [4,5]. Flowers in SD cultivars are initiated during colder temperatures and shorter photoperiods, and runnering is induced during warm temperatures and longer photoperiods. Open-field strawberry nurseries are in environments that promote runnering in SD cultivars. However, EB cultivars are specifically bred to target long season production, especially in central and south California [6-8]. While EB cultivars such as 'Monterey' or 'Fronteras' are the backbone of the current California strawberry industry, they bring significant challenges to the strawberry nursery industry. One of those challenges is the production of flowers in propagation fields, leading to additional disease attraction. Since the introduction of EB cultivars, manual flower removal has become common practice in strawberry nurseries in the US, leading to a significant increase in labor cost. While it is known that flowering responses of EB strawberry cultivars can be induced by nitrogen (N) treatments during field establishment [9-14], whereby higher nitrogen input improved flowering and yield overall [10], the impact of $\mathrm{N}$ sources on vegetative reproduction remains unclear. Optimized fertilizer protocols have the potential to improve nursery flower management. However, questions remain as to whether $\mathrm{N}$ sources can effectively lead to reduced flowering and/or increase propagation rates. It has been reported in the Orchid hybrid (Phalaenopsis Blume $\times$ Taisuco Kochdian) that the number of flowers declined when decreasing the nitrate percentage from $75 \%$ to $0 \%$ [15]. Therefore, a greenhouse study was conducted to investigate the effect of four nitrate-to-ammonium ratios on inflorescence and daughter plant production rate of the EB strawberry 'Albion'. The hypothesis is that increasing the ammonium percentage, i.e., decreasing the nitrate-to-ammonium ratio, reduces flowering production while maintaining similar vegetative growth (runnering).

\section{Materials and Methods}

\subsection{Experimental Design}

The experiment was conducted in a greenhouse on 40 strawberry plants (Fragaria $\times$ ananassa 'Albion') in a completely randomized block design. Four treatments of nutrient solutions with different nitrate to ammonium ratios $(v / v)$ were established: (1) 100\%:0\%; (2) $80 \%: 20 \%$; (3) $60 \%: 40 \%$; (4) $50 \%: 50 \%\left(\mathrm{NO}_{3}{ }^{-}: \mathrm{NH}_{4}{ }^{+}\right)$. The total concentration of $\mathrm{N}$ in the nutrient solution was $6 \mathrm{mmoL} / \mathrm{L}$ per treatment (Table 1). Nitrate sources were from potassium nitrate, calcium nitrate, and ammonium nitrate. Ammonium sources were from ammonium nitrate, ammonium dihydrogen phosphate, and ammonium sulfate. Potassium $(\mathrm{K})$, phosphorus $(\mathrm{P})$, and magnesium $(\mathrm{Mg})$ were consistent across treatments (Table 1). Chemicals were weighed (Mettler Toledo PL3030, Mettler-Toledo International Inc., Columbus, $\mathrm{OH}, \mathrm{USA}$ ) and dissolved in DI water. All nutrient solutions were delivered to plants by submersible pumps (Little Giant 500203 Lubricated pump, 1-A 170 GPH, Franklin Electric Co., Inc., Fort Wayne, IN, USA) through a drip irrigation system. Nutrient solutions were remade and refilled once per week over the course of the experiment.

In summer 2019, strawberry plug plants with a single crown were transplanted into 3.6 L planting pots and started to be fertilized according to the treatments. The experiment was conducted from 27 May to 19 August. The substrate filled in the planting pots was a mixing substrate with 50\%:50\% coconut coir/perlite $(v / v)$ (Mother Earth Coco + Perlite $\mathrm{Mix}^{\circledR}$, Hawthorne Gardening Co., Vancouver, WA, USA; 16,504 Horticultural Perlite, 17 L, Hoffman ${ }^{\circledR}$, San Jose, CA, USA). Strawberry plants were growing at $26.2^{\circ} \mathrm{C}$ on average in a $16 \mathrm{~h}$ photoperiod with $80 \mu \mathrm{moL} \cdot \mathrm{m}^{-2} \cdot \mathrm{s}^{-1}$ of LED supplemental light (KingPlus $1500 \mathrm{~W}$ Full Spectrum, Shenzhen King Lighting Co., Shenzhen, China). Light was supplemented daily from 6:00 to 8:00 a.m. and again from 4:00 to 10:00 p.m. Previous studies have shown that long photoperiods lead to increased daughter plant production in 'Albion' [16]. The irrigation occurred twice a day at 9:00 a.m. and 3:00 p.m. with $250 \mathrm{~mL}$ input per pot. Feed and drain volume were monitored daily. Feed and drain from each treatment were collected to monitor the volume, $\mathrm{pH}$, and $\mathrm{EC}$, as well as to calculate the drainage percentage. The $\mathrm{pH}$ and EC were tested using a $\mathrm{pH} / \mathrm{EC}$ meter (AI423 PC400S Portable Multi-Parameter Meter Kit, Apera Instruments. LLC, Columbus, OH, USA). Input and output nutrient 
solutions from each treatment were collected at 2 week intervals and analyzed for nutrient composition by the Agronomic Services at the North Carolina Department of Agriculture \& Consumer Services, Raleigh, NC, USA (Table 2).

Table 1. The chemical composition of feed nutrient solutions of the four treatments. The micronutrients were consistent among the treatments, as well as the amounts of potassium, phosphate, magnesium, and total nitrogen. The numbers are the concentration measured in $\mathrm{mmoL} / \mathrm{L}$ except when indicated in the table.

\begin{tabular}{|c|c|c|c|c|}
\hline \multirow{2}{*}{ Chemical } & \multicolumn{4}{|c|}{ Treatment } \\
\hline & $100 \% \mathrm{NO}_{3}^{-}: 0 \% \mathrm{NH}_{4}{ }^{+}$ & $80 \%: 20 \%$ & $60 \%: 40 \%$ & $50 \%: 50 \%$ \\
\hline $\mathrm{KH}_{2} \mathrm{PO}_{4}$ & 1 & 0 & 0 & 0 \\
\hline$\left(\mathrm{NH}_{4}\right)_{2} \mathrm{SO}_{4}$ & 0 & 0 & 0.4 & 1 \\
\hline $\mathrm{NH}_{4} \mathrm{H}_{2} \mathrm{PO}_{4}$ & 0 & 1 & 1 & 1 \\
\hline $\mathrm{MgSO}_{4}$ & 0.5 & 0.5 & 0.5 & 0.5 \\
\hline $\mathrm{KNO}_{3}$ & 2 & 3 & 3 & 3 \\
\hline $\mathrm{NH}_{4} \mathrm{NO}_{3}$ & 0 & 0.2 & 0.6 & 0 \\
\hline $\mathrm{Ca}\left(\mathrm{NO}_{3}\right)_{2}$ & 2 & 0.8 & 0 & 0 \\
\hline $\mathrm{CaCl}_{2}$ & 0 & 1.2 & 1.2 & 1.2 \\
\hline $\mathrm{Na}_{2} \mathrm{FeEDTA}$ & \multicolumn{4}{|c|}{$30 \mathrm{mg}$} \\
\hline $\mathrm{MnSO}_{4}$ & \multicolumn{4}{|c|}{0.01} \\
\hline $\mathrm{ZnSO}_{4}$ & \multicolumn{4}{|c|}{0.0008} \\
\hline $\mathrm{CuSO}_{4}$ & \multicolumn{4}{|c|}{0.0005} \\
\hline$\left(\mathrm{NH}_{4}\right)_{6} \mathrm{Mo}_{7} \mathrm{O}_{24}$ & \multicolumn{4}{|c|}{0.000085} \\
\hline $\mathrm{H}_{3} \mathrm{BO}_{3}$ & \multicolumn{4}{|c|}{0.05} \\
\hline
\end{tabular}

Table 2. Feed and drain of four fertilizer treatments. The concentration of each nutrient is presented in $\mathrm{mmoL} / \mathrm{L}$. The EC is presented in $\mathrm{dS} / \mathrm{cm}$. Data is presented as the mean \pm standard deviation $(n=6)$.

\begin{tabular}{|c|c|c|c|c|c|c|c|c|}
\hline \multirow{2}{*}{ Nutrients } & \multicolumn{4}{|c|}{ Feed } & \multicolumn{4}{|c|}{ Drain } \\
\hline & $100 \%: 0 \%$ & $80 \%: 20 \%$ & $60 \%: 40 \%$ & $50 \%: 50 \%$ & $100 \%: 0 \%$ & $80 \%: 20 \%$ & $60 \%: 40 \%$ & $50 \%: 50 \%$ \\
\hline $\mathrm{N}^{-\mathrm{NO}_{3}}{ }^{-}$ & $5.9 \pm 0.24$ & $4.6 \pm 0.15$ & $3.7 \pm 0.19$ & $2.6 \pm 1.25$ & $6.3 \pm 0.70$ & $5.1 \pm 0.51$ & $4.3 \pm 0.61$ & $2.9 \pm 1.44$ \\
\hline $\mathrm{N}-\mathrm{NH}_{4}{ }^{+}$ & $0.1 \pm 0.03$ & $1.3 \pm 0.04$ & $2.5 \pm 0.05$ & $3.0 \pm 0.08$ & $0.1 \pm 0.04$ & $0.9 \pm 0.19$ & $2.2 \pm 0.09$ & $2.9 \pm 0.15$ \\
\hline $\mathrm{P}$ & $1.0 \pm 0.07$ & $1.0 \pm 0.03$ & $1.1 \pm 0.03$ & $1.1 \pm 0.03$ & $1.2 \pm 0.04$ & $1.2 \pm 0.07$ & $1.3 \pm 0.20$ & $1.3 \pm 0.19$ \\
\hline $\mathrm{K}$ & $3.0 \pm 0.11$ & $2.9 \pm 0.08$ & $3.1 \pm 0.14$ & $2.6 \pm 1.22$ & $3.3 \pm 0.43$ & $3.1 \pm 0.26$ & $3.4 \pm 0.53$ & $2.8 \pm 1.42$ \\
\hline $\mathrm{Ca}$ & $2.1 \pm 0.1$ & $2 \pm 0.01$ & $1.3 \pm 0.02$ & $1.3 \pm 0.04$ & $2.3 \pm 0.23$ & $2.4 \pm 0.40$ & $1.8 \pm 0.59$ & $1.8 \pm 0.57$ \\
\hline $\mathrm{Mg}$ & $0.3 \pm 0.02$ & $0.3 \pm 0.01$ & $0.3 \pm 0.02$ & $0.3 \pm 0.09$ & $0.3 \pm 0.01$ & $0.3 \pm 0.03$ & $0.4 \pm 0.02$ & $0.3 \pm 0.1$ \\
\hline $\mathrm{S}$ & $0.7 \pm 0.04$ & $0.7 \pm 0.04$ & $1.2 \pm 0.06$ & $1.8 \pm 0.11$ & $0.9 \pm 0.12$ & $0.8 \pm 0.05$ & $1.5 \pm 0.23$ & $2.2 \pm 0.40$ \\
\hline $\mathrm{pH}$ & $6.6 \pm 0.13$ & $6.6 \pm 0.07$ & $6.5 \pm 0.08$ & $6.4 \pm 0.09$ & $6.4 \pm 0.08$ & $5.3 \pm 1.10$ & $5.1 \pm 0.99$ & $5.0 \pm 0.99$ \\
\hline $\mathrm{EC}$ & $1.1 \pm 0.03$ & $1.3 \pm 0.02$ & $1.3 \pm 0.04$ & $1.3 \pm 0.18$ & $1.2 \pm 0.14$ & $1.4 \pm 0.16$ & $1.5 \pm 0.26$ & $1.4 \pm 0.37$ \\
\hline
\end{tabular}

\subsection{Plant Material Preparation}

The daughter plants used in this experiment were harvested from 'Albion' strawberry stock plants that were fertilized with commercial fertilizer (N-P-K 20-10-20) in the greenhouse. To obtain plant materials to start this experiment, the daughter plants were rooted in 50-cell flats of growing media mix (Miracle-Gro Moisture Control Potting Mix, The Scotts Company LLC, Marysville, OH, USA) after being stored in the fridge at $4{ }^{\circ} \mathrm{C}$ for 1 week. The rooting of daughter plants took 2 weeks under a misting system and a subsequent 4 weeks under a sprinkler system until the plug plants were developed. No fertilizer was applied during rooting. The misting system automatically works in $10 \mathrm{~s}$ periods at $5 \mathrm{~min}$ intervals during the daytime. The sprinkler system was set to six times per day with $1 \mathrm{~min}$ duration. Plug plants with a fully developed root ball, a crown diameter of 1-1.5 mm, and 2-3 fully expanded leaves were transplanted into $4 \mathrm{~L}$ planting pots for the experiment. 


\subsection{Plant Traits and Data Analysis}

\subsubsection{Inflorescences}

Inflorescences were counted on a weekly basis when the inflorescence stalk and flower buds were visible. If there were primary flowers visible on the stalk, the inflorescence stalks were removed from the crowns after counting (Figure 1).

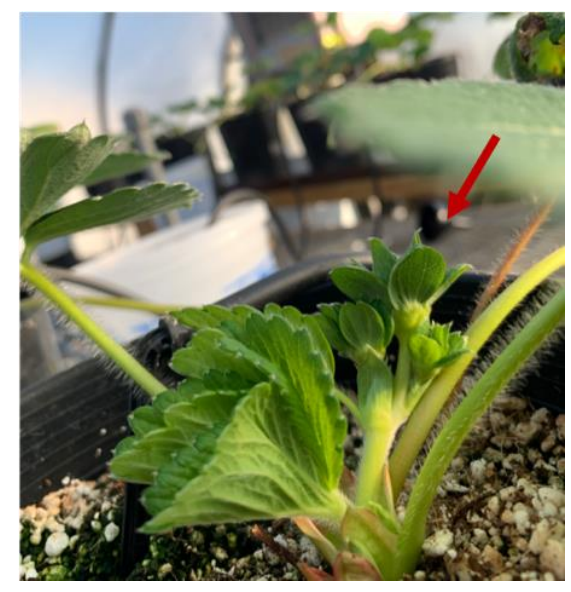

(a)

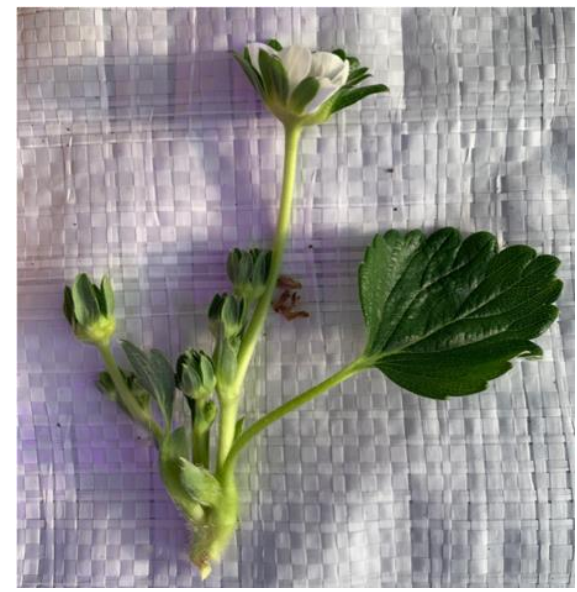

(b)

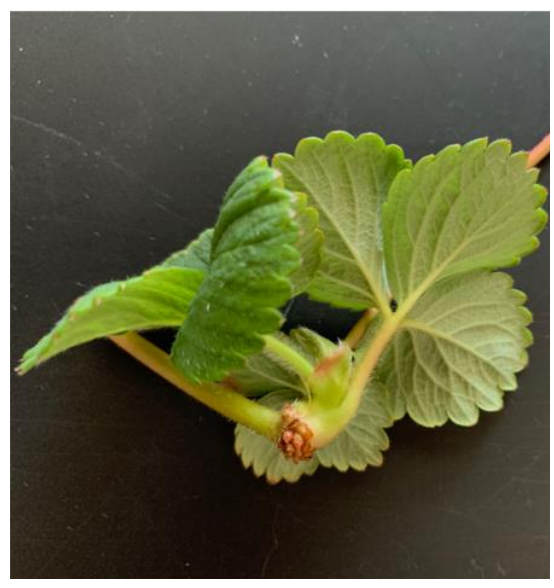

(c)

Figure 1. The inflorescence structure and daughter plant of strawberry plant 'Albion'. (a) An inflorescence to be counted with visible stalk and flower bud. The arrow points to the flower bud. (b) An inflorescence to be removed with visible primary flower and elongated stalk. (c) A strawberry ('Albion') daughter plant (runner tip) with three fully expanded leaves and visible rootlets [3].

\subsubsection{Daughter Plant}

Daughter plants were harvested in 2 week intervals when the rootlets of the daughter plants were visible and at least two leaves were fully expanded. Before harvest, the number of stolons attached to the mother plant was counted, and the total length of the first and second internode of a sympodial unit on a stolon was measured from the beginning of the first internode to the crown of corresponding daughter plant.

All harvested daughter plants were assessed for crown diameter, number of fully expanded leaves, number of visible roots, and dry mass. Crown diameter was measured on the widest diameter of the crown. Visible roots were counted. During each harvest, all daughter plants harvested from the same mother plant were placed into one paper bag and dried in a drying oven (Isotemp ${ }^{\circledR}$ Incubator Model 630D, Fisher Scientific Co. L.L.C. Pittsburgh, PA, USA) with air circulation at $80^{\circ} \mathrm{C}$ for at least $48 \mathrm{~h}$. Dry mass of the daughter plant was weighed individually using a precision balance (Mettler Toledo PL1502E, MettlerToledo International Inc., Columbus, OH, USA).

\subsubsection{Mother Plant Growth and Tissue Nutrient Analysis}

Mother plants from each treatment were sampled for tissue nutrient analysis twice during the experiment. Ten plants were sampled in each treatment. The mostly matured young leaf, including trifoliate blade and petiole, was cut off at the bottom of the plant and rinsed. Air-dried leaves were sent to the NCDA lab (North Carolina Department of Agriculture \& Consumer Services, Raleigh, NC, USA) for tissue nutrient analysis. Upon termination of this experiment, all 10 strawberry mother plants were measured for crown diameter and dry mass. The crown diameter was measured at narrow and wide length. Dry mass was determined using the same procedure described above. 


\subsubsection{Data Analysis}

Statistical data analysis was completed using SAS version 9.4 (SAS Institute Inc., Cary, NC, USA). To compare the effects of different $\mathrm{NO}_{3}{ }^{-}: \mathrm{NH}_{4}{ }^{+}$ratios on each parameter, an overall comparison of one-way ANOVA was conducted by using PROC GLM procedure of SAS, using a completely randomized design. The mean separation was subsequently determined using the Fisher protected LSD test to compare the treatment effects one by one, if there was a significantly overall difference. The significance level $\alpha=0.05$ was used to identify the difference between the treatments.

The cumulative number of inflorescences and daughter plants was calculated at each timepoint of data collection. The weekly cumulative inflorescence number was fitted in a quadratic linear regression model (cumulative inflorescence vs. week) using the PROC REG procedure of SAS. The cumulative daughter plant number was recorded biweekly due to the 2 week harvest interval. The cumulative daughter plant number per week was fitted into single linear regression model using the PROC REG procedure of SAS.

\section{Results}

\subsection{Inflorescence and Daughter Plant Production}

The inflorescence number of EB strawberry cultivar 'Albion' responded in a quadratic manner to the increasing percentage of $\mathrm{NH}_{4}^{+}$(Figure 2a). It increased when the percentage of $\mathrm{NH}_{4}{ }^{+}$increased from $0 \%$ to $20 \%$ and dropped as it increased from $20 \%$ to $50 \%$. The average number of inflorescences was $10.3 \pm 1.85$ stems per plant in the $80 \%: 20 \%$ treatment, while it was $5.7 \pm 1.24$ per plant in the $50 \%: 50 \%$, and $7.1 \pm 1.18$ in the $60 \%: 40 \%$ treatments. On the other hand, $8.8 \pm 1.19$ inflorescences were produced in the 100\%:0\% treatment. However, the production of daughter plants was not influenced by the percentage of $\mathrm{NH}_{4}{ }^{+}$ (Figure $2 \mathrm{~b}$ ). The dry mass of daughter plants, as well as the crown diameter of daughter plants, did not differ among treatments on any of the harvest days (Figure 3).

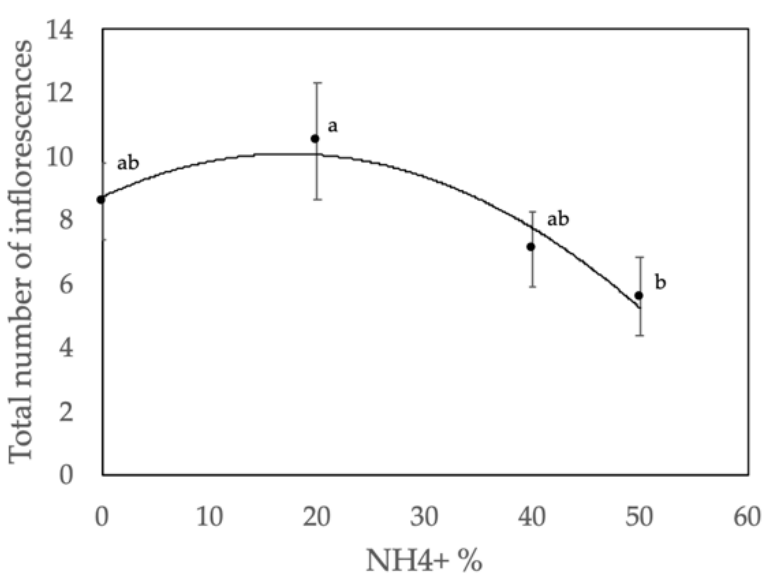

(a)

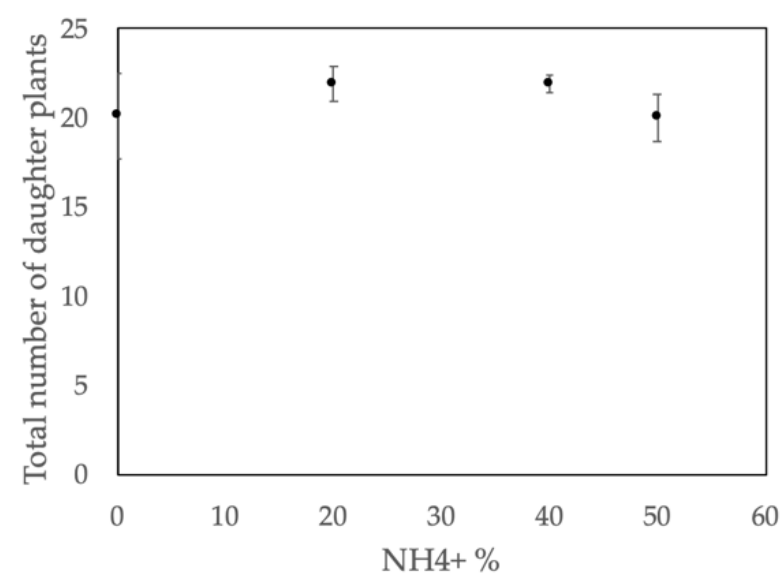

(b)

Figure 2. Average number of inflorescences and daughter plants under increasing percentage of $\mathrm{NH}_{4}{ }^{+}$(the remainder being $\mathrm{NO}_{3}{ }^{-}$). (a) Average number of inflorescences (Infl) produced under increasing percentage of $\mathrm{NH}_{4}{ }^{+}$. Shown are the mean and standard error $(n=10)$. Data were analyzed with regression analysis and fitted in a quadratic regression line: Infl $=12.16-0.09 \mathrm{NH}_{4}-0.005 \mathrm{NH}_{4}{ }^{2}(p$-value $=0.05)$. Letters indicate the mean separation between treatments (Tukey HSD, $\alpha=0.05$, $p$-value $=0.05)$. (b) Average number of daughter plants harvested under increasing percentages of $\mathrm{NH}_{4}{ }^{+}$. Shown are the mean and standard error $(n=10)$. No significant differences were found. 


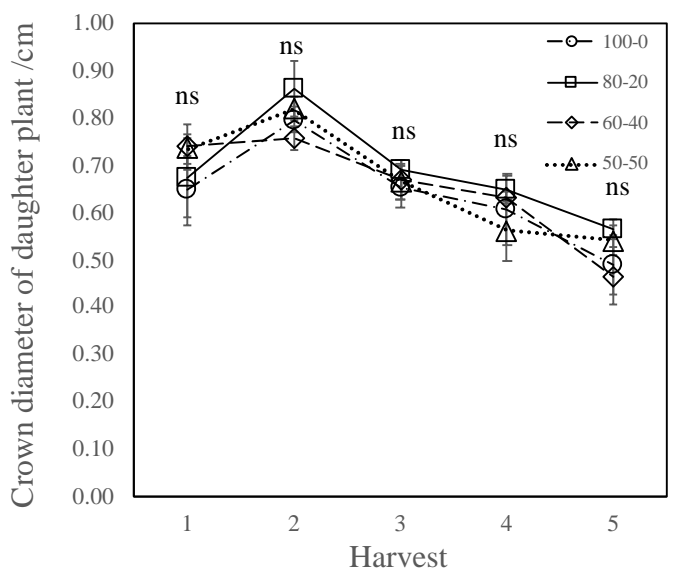

(a)

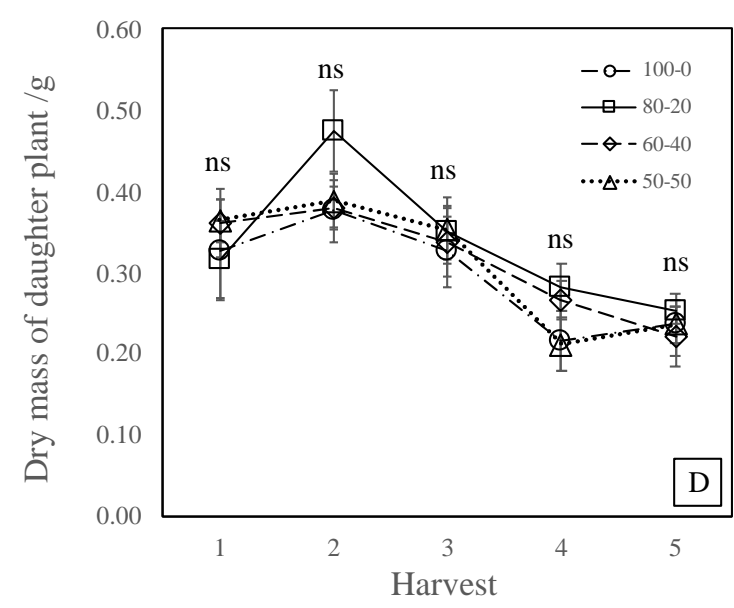

(b)

Figure 3. Average crown diameter and dry mass of daughter plants over five harvest days across the four treatments. (a) Average crown diameter $(\mathrm{cm})$ of daughter plants harvested in all treatments. Shown are the mean and standard error. No significant difference was found. (b) Average dry mass (g) over five harvest days across the four treatments. Shown are the mean and standard error. No significant differences were found.

\subsection{Mother Plant Growth}

The macronutrient content of leaf tissue samples of the mother plant did not significantly differ between the treatments (Table 3), nor did the total dry mass of the mother plant or crown diameter (Table 4).

Table 3. Macronutrient content (shown in \%) in leaf tissue sample of strawberry plants of four treatments. The leaf sample was taken from the youngest mature leaf twice during the experiment. Ten plants of each treatment were sampled at each sampling timepoint. Data are presented as the mean \pm standard deviation $(n=2)$. No statistical differences were observed between treatments.

\begin{tabular}{ccccccc}
\hline Treatments & $\begin{array}{c}\text { Nitrogen } \\
(\mathbf{N})\end{array}$ & $\begin{array}{c}\text { Phosphorus } \\
(\mathbf{P})\end{array}$ & $\begin{array}{c}\text { Potassium } \\
(\mathbf{K})\end{array}$ & $\begin{array}{c}\text { Calcium } \\
\text { (Ca) }\end{array}$ & $\begin{array}{c}\text { Sulphur } \\
\text { (S) }\end{array}$ & $\begin{array}{c}\text { Magnesium } \\
\text { (Mg) }\end{array}$ \\
\hline $100 \%: 0 \%$ & $2.9 \pm 0.23$ & $0.59 \pm 0.06$ & $2.72 \pm 0.59$ & $1.71 \pm 0.28$ & $0.15 \pm 0.00$ & $0.27 \pm 0.00$ \\
$80 \%: 20 \%$ & $2.9 \pm 0.18$ & $0.55 \pm 0.04$ & $2.68 \pm 0.38$ & $1.60 \pm 0.14$ & $0.18 \pm 0.04$ & $0.32 \pm 0.01$ \\
$60 \%: 40 \%$ & $3.0 \pm 0.08$ & $0.49 \pm 0.04$ & $2.58 \pm 0.06$ & $0.94 \pm 0.04$ & $0.21 \pm 0.06$ & $0.28 \pm 0.01$ \\
$50 \%: 50 \%$ & $3.2 \pm 0.25$ & $0.50 \pm 0.01$ & $2.73 \pm 0.11$ & $1.03 \pm 0.37$ & $0.27 \pm 0.08$ & $0.28 \pm 0.05$ \\
\hline
\end{tabular}

Table 4. Total dry mass and crown diameter of mother plants of four treatments. The mother plants were measured at the end of the experiment. Crown diameter is presented as the average of narrow and wide measurements. Data are presented as the mean \pm standard deviation $(n=10)$. No significant differences were detected between treatments.

\begin{tabular}{ccc}
\hline Treatments & $\begin{array}{c}\text { Dry Mass } \\
(\mathbf{g})\end{array}$ & $\begin{array}{c}\text { Crown Diameter } \\
(\mathbf{c m})\end{array}$ \\
\hline $100 \%: 0 \%$ & $22.81 \pm 10.94$ & $3.54 \pm 1.35$ \\
$80 \%: 20 \%$ & $18.38 \pm 8.61$ & $3.30 \pm 0.98$ \\
$60 \%: 40 \%$ & $16.63 \pm 5.62$ & $3.19 \pm 1.03$ \\
$50 \%: 50 \%$ & $19.63 \pm 6.07$ & $3.31 \pm 0.71$ \\
\hline
\end{tabular}




\section{Discussion}

\subsection{Nitrate-Ammonium Ratio Affects the Number of Inflorescences}

A decreased amount of nitrate and an increased amount of ammonium decreased inflorescence production in the EB strawberry 'Albion', while maintaining daughter plant production at similar rates. The total number of inflorescences was the highest in the 80\%:20\% treatment, compared to all other treatments. It has previously been shown that higher nitrogen rates enhance flowering in strawberry [9-14]. However, the effects of different nitrogen sources on strawberry reproductive traits have not been very well understood. According to Yamasaki et al. (2002), higher nitrate levels could stimulate flower production, while a further increase in ammonium is believed to inhibit flower initiation [17]. Yamazaki et al. (2002) showed this potential relationship in 'Toyonoka' strawberry, expressing reduced flower initiation under higher ammonium dosages [17]. Our treatments were selected on the basis of those findings, covering a range of $100 \%$ nitrate to $50 \%$ nitrate and $50 \%$ ammonium. Total nitrogen, including both forms of nitrate and ammonium, was constant at $6 \mathrm{mmoL} / \mathrm{L}$ across all treatments. While research in strawberry is limited, ammonium was found to significantly inhibit the uptake of nitrate, as compared to that observed with nitrate alone in barley $[18,19]$ and Arabidopsis [20]. We were also able to show reduced flowering under higher ammonium levels. The $80 \%: 20 \%$ treatment had more accessible nitrogen than the 100\%:0\% treatment due to high accessibility of $\mathrm{NH}_{4}{ }^{+}$to plants. Treatments of 60\%:40\% and 50\%:50\% with elevated $\mathrm{NH}_{4}{ }^{+}$levels showed reduced flowering. It is possible that the uptake of nitrate could be reduced by the higher percentage of $\mathrm{NH}_{4}{ }^{+}$in our treatments of $60 \%: 40 \%$ and 50\%:50\% [18-20]. It has also been shown that flowering can be regulated by nitrate in Arabidopsis. [21]. Flowering under different nitrogen rates was demonstrated as a U-shaped curve in the study of Lin and Tsay (2017) [21]. Flowering time (number of days after seed stratification) was reduced by increasing the nitrate content from 0.1 to $1.0 \mathrm{mmoL} / \mathrm{L}$ and increased after increasing the nitrate content from 1.0 to $2.0 \mathrm{mmoL} / \mathrm{L}$ in Arabidopsis thaliana [21]. Albeit in a different system, we could also observe a similar U-shaped curve under different nitrate levels in strawberry. However, it is important to emphasize the limitations of our study, which was based strictly on the assessment of morphological data. While we were able to indicate important effects of nitrogen fertilizer ratios on flowering in strawberry, more research will have to be conducted to understand the mechanisms behind those findings.

In our experiment, no symptoms of ammonium toxicity were observed, despite the reports of strawberry cultivars being sensitive to ammonium [22]. Claussen and Lenz (1999) revealed the sensitivity of strawberry by comparing the photosynthesis of strawberry plants fed with solely ammonium, solely nitrate, or solely ammonium with $\mathrm{CaCO}_{3}$ at a total nitrogen level of $6 \mathrm{mmoL} / \mathrm{L}$. The $6 \mathrm{mmoL} / \mathrm{L}$ of solely ammonium severely impaired the photosynthesis rate of strawberry [22]. However, the highest rate of ammonium used in this experiment was $3 \mathrm{mmoL} / \mathrm{L}$, which might have been below the toxic dose for strawberry plants. Cárdenas-Navarro et al. (2006) treated strawberry plants with ammonium alone at a nitrogen level of $4 \mathrm{mmoL} / \mathrm{L}$, revealing the same fresh mass as those treated with nitrate alone [23]. In our experiment, ammonium ratios were most likely below the threshold where visible ammonium toxicity symptoms would have been observed [24]. We did not observe any differences between treatments for daughter plant number, dry mass, or crown diameter.

\subsection{Nitrate-to-Ammonium Ratio Has No Effect on Daughter Plant Production}

Overall, propagation rates and daughter plant characteristics were not influenced by the different nitrate-to-ammonium ratio treatments. No statistical differences were observed between treatments in the total dry mass of mother plants (including leaves, crowns, and roots) or macronutrient content in leaf tissue. According to Brown and Wareign (1965), flowering and asexual production are controlled by different genetic loci in the wild strawberry (F. vesca) [25], although the two physiological processes seem to be antagonistic with regard to plant responses to temperature and photoperiod [26-28]. This 
almost mutually exclusive control of flowering induction and stolon formation (asexual reproduction) was also confirmed by Konsin et al. (2001) [29] and Heide and Sønsteby (2007) [30]. The exclusive control could explain why the flower production, but not daughter plant production was affected by different ratios of nitrate to ammonium. In addition, previous research showed that a mechanism allows the shoot meristem to quickly adapt to rapid changes of nitrate concentration in Arabidopsis [31]. It is possible that the daughter plant production was similar although the nitrogen supply status varied, resulting from the resilience of the shoot meristem of strawberry plants.

\section{Conclusions}

The results of this experiment are a further step in the direction of optimized fertilizer use in strawberry nurseries in the future. We showed that higher ammonium ratios in fertilizer solutions significantly decrease flower production in the long-day strawberry cultivar 'Albion', while maintaining daughter plant production. However, this study was conducted in a greenhouse container system under the consideration of strictly morphological traits. Further research is needed to understand the mechanisms behind our observations, eventually leading to optimized fertilizer management in strawberry nurseries.

Author Contributions: Conceptualization, M.H. and X.S.; methodology, M.H., R.H., and X.S.; formal analysis, X.S.; investigation, X.S.; resources, M.H. and X.S.; data curation, X.S. and M.H.; writingoriginal draft preparation, X.S.; writing—review and editing, M.H. and R.H.; visualization, X.S.; supervision, M.H.; project administration, M.H.; funding acquisition, M.H. All authors read and agreed to the published version of the manuscript.

Funding: This research was funded by USDA and the NC Strawberry Association.

Institutional Review Board Statement: Not applicable.

Informed Consent Statement: Not applicable.

Data Availability Statement: Data available upon request.

Acknowledgments: We thank Gina Fernandez (NCSU) for input to and discussion of the experiment. We further thank Tekan Rana, Emma Volk, and Rania Hassan for their help in collecting plant material.

Conflicts of Interest: The authors declare no conflict of interest.

\section{References}

1. National Statistics for Strawberries. USDA-NASS Report. 2019. Available online: https://www.nass.usda.gov/Statistics by_Subject/result.php?C6E91360-DC42-3C4A-8D5C-1392239A0EAF\&sector=CROPS\&group=FRUIT\%20\%26\%20TREE\%20 NUTS\&comm=STRAWBERRIES (accessed on 9 December 2021).

2. 2014 Census of Horticultural Specialties. USDA Census of Agriculture. 2014. Available online: https://www.nass.usda. gov/Publications/AgCensus/2012/Online_Resources/Census_of_Horticulture_Specialties/hortic_1_026_028.pdf (accessed on 9 December 2021).

3. Hancock, J.F. Strawberries; CAB International: Wallingford, UK, 1999; p. 237.

4. Heide, O.M.; Stavang, J.A.; Sønsteby, A. Physiology and genetics of flowering in cultivated and wild strawberries-A review. J. Hort. Sci. Biotechnol. 2013, 88, 1-18. [CrossRef]

5. Stewart, P.J.; Folta, K.M. A review of photoperiodic flowering research in strawberry (Fragaria spp.). Crit. Rev. Plant Sci. 2010, 29, 1-13. [CrossRef]

6. Neri, D.; Baruzzi, G.; Massetani, F.; Faedi, W. Strawberry production in forced and protected culture in Europe as a response to climate change. Can. J. Plant Sci. 2012, 92, 1021-1036. [CrossRef]

7. Castro, P.; Bushakra, J.M.; Stewart, P.; Weebadde, C.K.; Wang, D.; Hancock, J.F.; Finn, C.E.; Luby, J.J.; Lewers, K.S. Genetic mapping of day-neutrality in cultivated strawberry. Mol. Breed. 2015, 35, 79-94. [CrossRef]

8. Arnade, C.; Kuchler, F. Measuring the impact of off-season imports. U.S. Department Agriculture Economic Research Service. 2015. Available online: http:/ /www.ers.usda.gov/publications/err-economic-research-report/err197.aspx (accessed on 9 December 2021).

9. Durner, E.F. Programmed Flowering of The F1 Long-day Strawberry Cultivar 'Elan' via Nitrogen and Daylength Manipulation. AIMS Agri. Food. 2016, 1, 4-19. [CrossRef] 
10. Durner, E.F. Conditioning alleviates reduced yield of smaller plugs of 'Albion' strawberry (Fragaria X ananassa Duch.) in off-season plasticulture production. J. Hort. Sci. Biotech. 2017, 93, 433-440. [CrossRef]

11. Durner, E.F. Enhanced flowering of the F1 long-day strawberry cultivars "Tarpan" and "Gasana" with nitrogen and daylength management. AIMS Agri. Food. 2017, 2, 1-15. [CrossRef]

12. Durner, E.F. Fall nitrogen enhances spring nitrogen enhanced flowering in the long-day strawberry cultivar 'Elan'. AIMS Agri. Food. 2017, 2, 149-164. [CrossRef]

13. Durner, E.F. Long-day and nitrogen conditioning of 'Albion' strawberry (Fragaria $X$ ananassa Duch.) enhances off-season field production. J. Hort. Sci. Biotechnol. 2018, 93, 296-305. [CrossRef]

14. Durner, E.F. Plant architecture of 'Albion' strawberry (Fragaria $\times$ ananassa Duch.) is influenced by photoperiod and nitrogen but not light source during conditioning. AIMS Agri. Food. 2018, 3, 246-265. [CrossRef]

15. Wang, Y. High NO3-N to NH4-N Ratios Promote Growth and Flowering of a Hybrid Phalaenopsis Grown in Two Root Substrates. Hortscience 2008, 43, 350-353. [CrossRef]

16. Shi, X.; Hernández, R.; Hoffmann, M. Timing of stolon removal alters daughter plant production and quality in the ever-bearing strawberry 'Albion'. HortScience 2021, 56, 650-656. [CrossRef]

17. Yamasaki, A.; Yoneyama, T.; Tanaka, F.; Tanaka, K.; Nakashima, N. Tracer studies on the allocation of carbon and nitrogen during flower induction of strawberry plants as affected by the nitrogen level. Acta Hortic. 2002, 567, 349-352. [CrossRef]

18. Kronzucker, H.J.; Glass, A.D.M.; Siddiqi, M.Y. Inhibition of nitrate uptake by ammonium in barley. Analysis of component fluxes Plant Physiol. 1999, 120, 283-291. [CrossRef] [PubMed]

19. Kronzucker, H.J.; Siddiqi, M.Y.; Glass, A.D.; Kirk, G.J. Nitrate- ammonium synergism in rice. A subcellular flux analysis. Plant Physiol. 1999, 119, 1041-1046. [CrossRef] [PubMed]

20. Cerezo, M.; Tillard, P.; Filleur, S.; Muños, S.; Daniel-Vedele, F.; Gojon, A. Major alterations of the regulation of root $\mathrm{NO}_{3}{ }^{-}$uptake are associated with the mutation of Nrt2.1 and Nrt2.2 genes in Arabidopsis. Plant Physiol. 2001, 127, 262-271. [CrossRef] [PubMed]

21. Lin, Y.L.; Tsay, T.F. Influence of differing nitrate and nitrogen availability on flowering control in Arabidopsis. J. Exp. Bot. 2017, 68, 2603-2609. [CrossRef] [PubMed]

22. Claussen, W.; Lenz, F. Effect of ammonium or nitrate nutrition on net photosynthesis, growth, and activity of the enzymes nitrate reductase and glutamine syntheses in blueberry, raspberry and strawberry. Plant Soil. 1999, 208, 95-102. [CrossRef]

23. Cárdenas-Navarro, R.; López-Pérez, L.; Lobit, P.; Ruiz-Corro, R.; Castellanos-Monrales, V.V. Effects of nitrogen source on growth and development of strawberry plants. J. Plant Nutr. 2006, 29, 1699-1707. [CrossRef]

24. Marino, D.; Moran, J.F. Can ammonium stress be positive for plant performance? Front. Plant Sci. 2019, 10, 1103. [CrossRef]

25. Brown, T.; Wareign, P.F. The genetic control of the everbearing habit and three other characters in varieties of Fragaria vesca. Euphytica 1965, 14, 97-112. [CrossRef]

26. Ito, H.; Saito, T. Studies on the flower formation in the strawberry plant. I. Effects of temperature and photoperiod on the flower formation. Tohoku J. Agri. Res. 1962, 13, 191-203.

27. Remay, A.; Lalanne, D.; Thouroude, T.; Le Couvier, F.; Oyant, L.H.-S.; Foucher, F. A survey of flowering genes reveals the role of gibberellins in floral control in rose. Theor. Appl. Genet. 2009, 119, 767-781. [CrossRef] [PubMed]

28. Koskela, E.A.; Mouhu, K.; Albani, M.C.; Kurokura, T.; Ranta-Nen, M.; Sargent, D.J.; Battey, N.H.; Coupland, G.; Elomaa, P.; Hytönen, T. Mutation in TERMINAL FLOWER1 reverses the photoperiodic requirement for flowering in the wild strawberry Fragaria Vesca. Plant Physiol. 2012, 159, 1043-1054. [CrossRef] [PubMed]

29. Konsin, M.; Voipio, I.; Palonen, P. Influence of photoperiod and duration of short-day treatment on vegetative growth and flowering of strawberry (Fragaria $\times$ ananassa Duch.). J. Hortic. Sci. Biotechnol. 2001, 76, 77-82. [CrossRef]

30. Heide, O.M.; Sønsteby, A. Interactions of temperature and photoperiod in the control of flowering of latitudinal and altitudinal populations of wild strawberry (Fragaria vesca). Physiol. Plantarum. 2007, 130, 280-289. [CrossRef]

31. Landrein, B.; Formosa-Jordan, P.; Malivert, A.; Schuster, C.; Melnyk, C.W.; Yang, W.; Turnbull, C.; Meyerowitz, E.M.; Locke, J.C.W.; Jönsson, H. Nitrate modulation of Arabidopsis shoot stem cells. Proc. Natl. Acad. Sci. USA 2018, 115, 1382-1387. [CrossRef] [PubMed] 